\title{
Pengaruh Sistem Pengendalian Intern Pemerintah dan Moralitas Individu Pada Kesalahan Akuntansi
}

\section{Gusti Agung Gde Dennyningrat ${ }^{1}$ I D.G. Dharma Suputra ${ }^{2}$}

${ }^{1}$ Fakultas Ekonomi dan Bisnis Universitas Udayana (Unud), Bali, Indonesia email: dennyningrat@yahoo.com

${ }^{2}$ Fakultas Ekonomi dan Bisnis Universitas Udayana (Unud), Bali, Indonesia

\begin{abstract}
ABSTRAK
Kesalahan akuntansi merupakan kesalahan fakta keuangan. Agar dalam suatu instansi atau perusahaan tidak terjadi kesalahan akuntansi, instansi atau perusahaan perlu memperhatikan faktor-faktor yang mempengaruhi kesalahan akuntansi. Tujuan penelitian ini adalah untuk memberi bukti empiris pengaruh Sistem Pengendalian Intern Pemerintah dan moralitas individu pada kesalahan akuntansi. Penelitian ini dilakukan pada Pemerintah Daerah Kabupaten Badung. Populasi dalam penelitian ini adalah seluruh pegawai bagian keuangan pada Pemerintah Kabupaten Badung. Jumlah sampel yang diambil sebanyak 35 pegawai, dengan teknik purposive sampling. Pengumpulan data dilakukan dengan metode kuesioner. Teknik analisis data yang digunakan adalah analisis regresi linier berganda. Berdasarkan hasil analisis, diketahui bahwa Sistem Pengendalian Intern Pemerintah dan moralitas individu berpengaruh negatif pada kesalahan akuntansi pada Pemerintah Daerah Kabupaten Badung.

Kata kunci: sistem pengendalian intern, moralitas individu, kesalahan akuntansi
\end{abstract}

\begin{abstract}
Accounting mistakes are a mistake in financial facts. In order for an agency or company does not occur accounting errors, agencies or companies need to consider the factors that affect accounting errors. The purpose of this study is to provide empirical evidence of the effect of Government Internal Control System and individual morality on accounting errors. This research was conducted at Local Government of Badung Regency. Population in this research is all financial officer at Badung Regency Government. The number of samples taken as many as 35 employees, with purposive sampling technique. The data were collected by questionnaire method. Data analysis technique used is multiple linear regression analysis. Based on the results of the analysis, it is known that the Government Internal Control System and individual morality have a negative effect on accounting errors in Badung District Government.
\end{abstract}

Keywords: internal control system, individual morality, accounting error

\section{PENDAHULUAN}

Dunia akuntansi yang kian berkembang tidak hanya membawa pengaruh baik untuk masyarakat, namun juga membawa pengaruh buruk seperti halnya masalah kesalahan akuntansi yang cenderung masih sering terjadi baik dalam skala kecil maupun besar (Nadya, 2016:1). Pada dasarnya ada dua tipe kesalahan akuntansi 
I Gusti Agung Gde Dennyningrat dan I D. G. Dharma Suputra. Pengaruh...

yang terjadi di suatu instansi ataupun perusahaan, yaitu kesalahan akuntansi yang disengaja dan kesalahan akuntansi yang tidak disengaja (Hartadi, 2004:72).

Kesalahan akuntansi yang disengaja timbul dari perbuatan orang-orang yang tidak jujur dengan perbuatan kesengajaan. Kesalahan akuntansi yang tidak disengaja dapat disebabkan karena tidak berfungsinya secara teliti alat yang digunakan, karena sistem terlalu banyak pekerjaan-pekerjaan, salah mengerti atau tafsir perintah atau prosedur oleh karyawan, atau kesalahan manusia yang meliputi kecerobohan dan kekeliruan pertimbangan. Kedua jenis kesalahan ini dapat bersifat material dan non material. Perbedaan antara kedua jenis kesalahan ini hanya dibedakan oleh jurang yang sangat tipis, yaitu ada atau tidaknya unsur kesengajaan. Kkeahlian profesional dibutuhkan untuk bisa membedakan antara kedua jenis kesalahan tersebut (Agoes, 2007:3). Sering kali dalam mendeteksi kesalahan yang disengaja lebih sulit dibandingkan dengan kesalahan yang tidak disengaja karena pihak manajemen atau karyawan akan berusaha menyembunyikan kesalahan tersebut.

Kesalahan akuntansi yang terjadi di pemerintahan menyebabkan data dan informasi laporan keuangan yang diterbitkan oleh pemerintah menjadi tidak objektif dan dapat menyesatkan pengguna laporan keuangan dalam menilai kinerja atau bahkan dalam pengambilan keputusan. Hal tersebut akan menghambat tercapainya tujuan dari akuntansi pemerintahan, yaitu (a) menjaga keuangan publik dengan mencegah dan mendeteksi tindakan korupsi dan tindakan untuk mencari keuntungan secara tidak beretika, (b) memfasilitasi pengelolaan keuangan pemerintahan secara sehat, (c) membantu pemerintah dalam 
memberikan akuntabilitas kepada masyarakat (Wilopo, 2006). Kesalahan akuntansi bisa dicegah sekecil mungkin jika disusun sistem akuntansi yang baik. Selain itu untuk mencegah timbulnya kesalahan-kesalahan itu biasanya dilakukan pemeriksaan intern oleh karyawan perusahaan (Wadiyo, 2016).

Kesalahan akuntansi terjadi disebabkan oleh lemahnya pengendalian intern. Sistem pengendalian intern di lingkungan instansi pemerintah dikenal sebagai suatu sistem yang diciptakan untuk mendukung upaya agar penyelenggaraan kegiatan pada instansi pemerintahan dapat mencapai tujuannya secara efisien dan efektif, dimana pengelolaan keuangan negara dapat dilaporkan secara andal, aset negara dapat dikelola dengan aman, dan tentunya mendorong ketaatan terhadap peraturan perundang-undangan. Sistem Pengendalian Intern Pemerintah dalam penerapannya harus senantiasa memperhatikan norma keadilan dan kepatutan serta mempertimbangkan ukuran, kompleksitas dan sifat dari tugas dan fungsi instansi pemerintah (PP No 60 Tahun 2008). Penerapan Sistem Pengendalian Intern Pemerintah (SPIP) merupakan sebuah konsekuensi logis bagi sebuah institusi dalam menjalankan tugas dan fungsinya. Setiap lembaga Pemerintah sebaiknya memiliki suatu sistem pengendalian yang dapat meminimalkan risiko yang ada.

Sistem Pengendalian Intern Pemerintah (SPIP) yang buruk juga akan membuat peluang untuk tidak jujur. Menurut Permendagri Nomor 13 Tahun 2006 diperbarui Nomor 59 tahun 2007 diperbarui Nomor 21 tahun 2011 sistem akuntansi pemerintahan meliputi serangkaian prosedur, mulai dari proses pengumpulan data, pencatatan, penggolongan, dan peringkasan atas transaksi atau 
I Gusti Agung Gde Dennyningrat dan I D. G. Dharma Suputra. Pengaruh...

kejadian keuangan serta pelaporan keuangan dalam rangka pertanggung jawaban pelaksanaan APBD yang dapat dilakukan secara manual atau menggunakan aplikasi komputer. Untuk menyelenggarakan akuntansi pemerintah daerah, kepala daerah menetapkan sistem akuntansi pemerintahan daerah dengan mengacu pada peraturan daerah tentang pokok-pokok pengelolaan keuangan daerah, disusun dengan berpedoman pada prinsip pengendalian intern dan standar akuntansi pemerintahan.

Moralitas individu juga berperan penting dalam kesalahan akuntansi yang cenderung masih saja terjadi selain faktor pengendalian intern. Moral merupakan hal yang sesuai dengan keyakinan umum yang diterima masyarakat, berkaitan dengan penilaian norma tindakan manusia. Semakin tinggi level penalaran moral individu, maka akan semakin cenderung untuk tidak melakukan kecurangan akuntansi (Wilopo, 2006).

Kesalahan akuntansi sangat berkaitan dengan tingkat moralitas individu tersebut karena hal tersebut merupakan perilaku yang ilegal. Menurut Baucus (1994) dalam Hernandez dan Groot (2007), perilaku ilegal menjadi bagian dari perilaku tidak etis, sehingga perlu adanya ketentuan hukum yang mengikat sebagai salah satu usaha penegakkan standar moralitas individu agar kehidupan masyarakat seluruhnya dapat terjaga. Hernandez dan Groot (2007) menunjukkan hasil penelitian bahwa lingkungan pengendalian akuntansi dan etika seseorang merupakan dua hal yang saling berkaitan dengan kecenderungannya dalam melakukan suatu kesalahan akuntansi. 
Moralitas individu dan perilaku yang melekat pada diri individu tersebut menjadi aspek yang berhubungan dengan faktor individu (internal). Salah satu teori perkembangan moral yang sering digunakan dalam penelitian tentang etika seseorang adalah model Kohlberg. Kohlberg (1971) menjelaskan bahwa moral berkembang melalui tiga tahapan, yaitu tahapan pre-conventional, tahapan conventional dan tahapan post-conventional. Penelitian ini dilakukan dengan tujuan yaitu 1) untuk memberi bukti empiris pengaruh Sistem Pengendalian Intern Pemerintah pada kesalahan akuntansi, 2) untuk memberi bukti empiris pengaruh moralitas individu pada kesalahan akuntansi.

Landasan teori yang digunakan dalam penelitian ini adalah teori perkembangan moral. Teori perkembangan moral yang sering dipakai dalam penelitian tingkat etika adalah model Kohlberg. Teori ini mempunyai pandangan bahwa penalaran moral merupakan landasan perilaku etis. Menurut Kohlberg (1971) tahapan perkembangan moral merupakan ukuran dari tinggi rendahnya moral seseorang berdasarkan perkembangan penalaran moralnya. Ia melakukan penelitian berdasarkan kasus dilema moral untuk mengamati perbedaan perilaku individu dalam menyikapi persoalan moral yang sama. Kemudian ia membuat klasifikasi atas respon dari setiap individu ke dalam enam tahap yang berbeda. Terdapat tiga tahapan perkembangan moral, yaitu tahapan pre-conventional, tahapan conventional dan tahapan post-conventional.

Herman (2013) yang meneliti pengaruh keadilan organisasi dan sistem pengendalian intern tehadap kecurangan membuktikan bahwa sistem pengendalian intern berpengaruh negatif terhadap kecurangan pada kantor cabang 
I Gusti Agung Gde Dennyningrat dan I D. G. Dharma Suputra. Pengaruh...

utama bank pemerintah di Kota Padang. Hal ini berarti bahwa sistem pengendalian intern memiliki pengaruh yang besar terhadap kelangsungan perusahaan, dengan sistem pengendalian intern yang baik, maka perusahaan dapat melaksanakan seluruh aktifitasnya sesuai dengan tujuan dan sasaran yang ingin dicapai, jika tujuan perusahaan telah tercapai berarti tindakan karyawan telah sesuai dengan peraturan dan tidak ada tindakan yang merugikan perusahaan. Faktanya beberapa tindakan kecurangan terjadi disebabkan oleh lemahnya sistem pengendalian internal.

Michel (2013) yang meneliti mengenai pengaruh pelaksanaan sistem pengendalian intern pemerintah dan peran inspektorat terhadap penyalahgunaan aset menunjukkan bahwa pelaksanaan SPIP berpengaruh negatif terhadap penyalahgunaan aset. Hal ini berarti semakin baik pelaksanaan SPIP maka tindakan penyalahgunaan aset akan semakin berkurang. Berdasarkan penelitian Wilopo (2006), mengenai analisis faktor-faktor yang berpengaruh terhadap kecenderungan kecurangan akuntansi: studi pada perusahaan publik dan badan usaha milik negara di Indonesia, hasil penelitiannya menunjukkan bahwa pengendalian intern yang efektif memberikan pengaruh yang negatif terhadap kecenderungan kecurangan akuntansi di perusahaan tersebut, hal ini menunjukkan bahwa semakin efektif pengendalian intern diperusahaan, semakin rendah kecenderungan kecurangan akuntansi.

$\mathrm{H}_{1}$ : Sistem Pengendalian Intern Pemerintah berpengaruh negatif pada kesalahan akuntansi

Teori perkembangan moral Kohlberg (1971) menyatakan bahwa moral berkembang melalui tiga tahapan, yaitu tahapan pra konvensional, tahapan 
konvensional dan tahapan pasca konvensional. Moralitas individu yang berada pada tahapan pasca konvensional menunjukkan kematangan moral dengan tingkat yang tinggi. Individu tersebut dapat merancang tanggapan dan menunjukkan sikap yang lebih relevan terhadap isu-isu etis dalam kematangan moral telah tercapai pada tingkat ini.

Moral merupakan hal yang sesuai dengan keyakinan umum yang diterima masyarakat, berkaitan dengan penilaian norma tindakan manusia. Moralitas individu akan berhubungan pada kecenderungan seseorang untuk melakukan kecurangan akuntansi. Semakin tinggi level penalaran moral individu, maka akan semakin cenderung untuk tidak melakukan kecurangan akuntansi (Wilopo, 2006). Oleh sebab itu, kecurangan akuntansi dalam suatu lembaga akan dipengaruhi oleh moralitas individu dari para pegawai yang bekerja di dalamnya. Suatu perusahaan tentu memiliki banyak individu yang bekerja pada masing-masing bagiannya. Setiap individu tersebut tentu memiliki level moralitas beragam dan akan sangat berpengaruh terhadap kecenderungan kecurangan akuntansi yang mungkin timbul. Moralitas individu akan berpengaruh pada perilaku etisnya. Orang dengan level penalaran moral yang rendah memiliki perilaku berbeda dengan orang yang memiliki level penalaran moral yang tinggi saat menghadapi dilema etika. Terdapat bukti empiris dari Graham (1995) dan Patterson (2001) yang menemukan bahwa individu dengan level penalaran moral rendah lebih berorientasi pada peraturan dan sanksi hukum yang mungkin didapatkan.

Liyanarachi (2009) mengungkapkan bahwa orang dengan level penalaran moral rendah cenderung melakukan hal-hal yang menguntungkan kepentingan 
I Gusti Agung Gde Dennyningrat dan I D. G. Dharma Suputra. Pengaruh...

dirinya sendiri dan akan menghindari hal-hal yang dapat menimbulkan sanksi hukum. Hal ini juga dapat berarti bahwa semakin tinggi moralitas individu, yaitu pada tingkat pasca konvensional, maka individu tersebut akan lebih memperhatikan kepentingan masyarakat luas dibandingkan kepentingan organisasinya, apalagi kepentingan pribadinya. Pada tingkat ini, individu yang mempunyai level penalaran moral tinggi tersebut akan memikirkan kepentingan masyarakat luas dengan berdasarkan pada prinsip moral. Oleh sebab itu, semakin tinggi moralitas individu, maka semakin ia akan berusaha untuk menghindari kecenderungan kecurangan akuntansi. Ini berarti moralitas individu berpengaruh negatif terhadap kecenderungan kecurangan akuntasi.

$\mathrm{H}_{2}$ : $\quad$ Moralitas individu berpengaruh negatif pada kesalahan akuntansi

\section{METODE PENELITIAN}

Pendekatan yang digunakan dalam penelitian ini adalah pendekatan yang berbentuk asosiatif. Penelitian asosiatif adalah penelitian yang bertujuan untuk mengetahui hubungan antara dua variabel atau lebih (Sugiyono, 2014:55). Penelitian ini membahas pengaruh Sistem Pengendalian Intern Pemerintah dan moralitas individu pada kesalahan akuntansi pada Pemerintah Daerah Kabupaten Badung. Penelitian ini dilakukan pada Pemerintah Daerah Kabupaten Badung. Lokasi tersebut dipilih karena di dalam Pemerintahan Daerah Kabupaten Badung menerapkan Sistem Pengendalian Intern Pemerintah.

Variabel dependen (dependent variable) pada penelitian ini adalah kesalahan akuntansi. Pada Bab Akuntansi Koreksi Kesalahan dalam Permendagri no. 64 tahun 2013 tentang Penerapan Standar Akuntansi Pemerintahan Berbasis 
Akrual pada Pemerintah Daerah, ada beberapa penyebab bisa terjadinya kesalahan. Antara lain disebabkan karena keterlambatan penyampaian bukti transaksi oleh pengguna anggaran, kesalahan hitung, kesalahan penerapan standar dan akuntansi, kelalaian, dan lain-lain. Kesalahan juga bisa ditemukan di periode yang sama saat kesalahan itu dibuat, namun bisa pula ditemukan pada periode di masa depan. Itulah sebabnya akan ada perbedaan perlakuan terhadap beberapa kesalahan tersebut. Kesalahan diukur dengan melihat indikator penyebab dari kesalahan akuntansi itu bisa terjadi. Daftar pernyataan terdiri dari 5 pernyataan. Frekuensi kesalahan diukur berdasarkan skala likert 1 - 4. Skala 1 TP (Tidak Pernah), artinya kesalahan akuntansi tidak pernah terjadi di lokasi penelitian, skala 2 JR (Jarang), artinya kesalahan akuntansi pernah terjadi di lokasi penelitian dengan tingkat yang rendah, skala 3 SR (Sering), artinya kesalahan akuntansi pernah terjadi di lokasi penelitian dengan tingkat yang cukup tinggi, dan skala $4 \mathrm{~S}$ (Selalu), artinya kesalahan akuntansi yang terjadi di lokasi penelitian sangat tinggi.

Variabel independen (independent variable) dalam penelitian ini terdiri dari sistem pengendalian intern pemerintah dan moralitas individu. Sistem Pengendalian Intern Pemerintah $\left(\mathrm{X}_{1}\right)$ adalah proses yang integral pada tindakan dan kegiatan yang dilakukan secara terus menerus oleh pimpinan dan seluruh pegawai untuk memberikan keyakinan memadai atas tercapainya tujuan organisasi melalui kegiatan yang efektif dan efisien, keandalan pelaporan keuangan, pengamanan aset negara, dan ketaatan terhadap peraturan perundangundangan. Variabel ini diukur dengan instrumen yang telah digunakan oleh 
I Gusti Agung Gde Dennyningrat dan I D. G. Dharma Suputra. Pengaruh...

Lestari (2014:46). Sistem Pengendalian Intern Pemerintah diukur berdasarkan lima indikator yaitu lingkungan pengendalian, penilaian risiko, kegiatan pengendalian, informasi dan komunikasi, serta pemantauan. Daftar pernyataan terdiri dari 15 pernyataan. Frekuensi SPIP di ukur berdasarkan skala likert 1- 4 . Skala 1 TP (Tidak Pernah), artinya SPIP sangat rendah. Skala 4 S (Selalu), artinya SPIP sangat tinggi.

Moralitas individu $\left(\mathrm{X}_{2}\right)$ yang digunakan dalam penelitian ini mengacu pada teori perkembangan moral Kohlberg (1971) yang menyatakan bahwa moral berkembang melalui tiga tahapan, yaitu tahapan pre-conventional, tahapan conventional dan tahapan post-conventional. Pengukuran moralitas berasal dari model pengukuran moral oleh Kohlberg (1971) dalam bentuk instrumen Defining Issues Test Test (DIT) yang dirancang untuk mengukur kapasitas moral kognitif, yaitu tingkat penalaran moral yang mampu dilakukan oleh seorang individu. Instrumen ini berbentuk kasus dilema etika yang dikembangkan dalam penelitian Nadya (2016:51). Moralitas diukur melalui 6 butir instrumen yang mengukur setiap tahapan moralitas melalui kasus dilema etika akuntansi. Setiap tahapan moralitas ditunjukkan dengan skala satu sampai dengan empat, selanjutnya dilakukan penjumlahan hasil skala dari keenam instrumen tersebut. Hasil pengukuran atas dilema etika akuntansi ini merupakan cerminan moralitas individu. Semakin rendah hasil penjumlahan skala dari instrumen tersebut, maka tingkat moralitas individu tersebut masih berada pada tahap yang rendah yaitu level pre-conventional. 
Sumber data yang digunakan dalam penelitian ini adalah data primer dan data sekunder. Data primer merupakan data yang diperoleh langsung dari sumbernya, diamati, dicatat untuk pertama kalinya (Sugiyono, 2014: 129). Data primer pada penelitian yaitu berupa hasil kuesioner atau jawaban dari responden. Data sekunder pada penelitian ini adalah gambaran umum Pemerintah Daerah Kabupaten Badung.

Populasi dalam penelitian ini adalah seluruh pegawai bagian keuangan pada Pemerintah Kabupaten Badung. Instansi yang digunakan adalah Dinas Daerah pada Pemerintah Kabupaten Badung, dengan jumlah pegawai bagian keuangan sebanyak 76 orang. Penelitian ini menggunakan teknik purposive sampling sebagai metode penentuan sampel. Kriteria penentuan sampel pada penelitian ini yaitu pegawai bagian keuangan yang memiliki pengalaman kerja minimal 1 tahun dan pegawai yang sudah ditetapkan sebagai Pegawai Negeri Swasta (PNS). Adapun pegawai yang masuk dalam kriteria yaitu sebanyak 63 pegawai. Jumlah 63 sudah memenuhi kriteria dalam teknik purposive sampling karena, dari semua sampel tersebut, sebanyak 63 pegawai telah bekerja lebih dari 1 tahun dan sudah ditetapkan sebagai PNS. Dipilih telah bekerja satu tahun dan sudah ditetapkan sebagai PNS karena telah memiliki waktu dan pengalaman untuk beradaptasi serta menilai kondisi lingkungan kerjanya (Wibowo, 2009:19).

Teknik analisis data yang digunakan untuk memecahkan permasalahan yang terdapat dalam penelitian ini adalah analisis regresi linear berganda. Uji hipotesis melalui analisis regresi linier berganda (multiple), adalah untuk mencari pengaruh sistem pengendalian intern pemerintah $\left(\mathrm{X}_{1}\right)$ dan moralitas individu terhadap 
I Gusti Agung Gde Dennyningrat dan I D. G. Dharma Suputra. Pengaruh...

kesalahan akuntansi (Y). Model analisis regresi linier berganda yang digunakan adalah dengan menggunakan rumus (Sugiyono, 2014: 277):

$$
\begin{aligned}
\mathrm{Y}=\alpha & +\beta_{1} \mathrm{X}_{1}+\beta_{2} \mathrm{X}_{2}+\beta_{3} \mathrm{X}_{3}+\mathrm{e} \ldots \ldots \ldots \ldots \ldots \ldots \ldots \ldots \ldots \ldots \ldots \ldots \ldots \ldots \ldots \ldots \ldots \ldots \ldots \ldots \ldots \\
\text { Keterangan: } & \\
\mathrm{Y} & =\text { Kesalahan Akuntansi } \\
\alpha & =\text { konstan } \\
\mathrm{X}_{1} & =\text { Sistem Pengendalian Intern Pemerintah } \\
\mathrm{X}_{2} & =\text { Moralitas Individu } \\
\beta_{1} & =\text { koefisien regresi teknik Sistem Pengendalian Intern Pemerintah } \\
\beta_{2} & =\text { koefisien regresi Moralitas Individu } \\
\mathrm{e} & =\text { komponen pengganggu }
\end{aligned}
$$

\section{HASIL DAN PEMBAHASAN}

Data penelitan yang dikumpulkan berupa kuesioner yang disebarkan langsung ke seluruh responden yang bersangkutan. Kuesioner tersebut ditinggal dan diambil kembali antara 2 hari sampai 2 minggu setelah kuesioner diserahkan. Distribusi mengenai penyebaran kuesioner disajikan dalam Tabel 1.

Tabel 1.

Rincian Pengiriman dan Pengembalian Kuesioner

\begin{tabular}{lcc}
\hline \multicolumn{1}{c}{ Keterangan } & Jumlah & Persentase \\
\hline Total kuisioner yang disebar & 63 & $100 \%$ \\
Jumlah kuisioner yang kembali & 35 & $55,56 \%$ \\
Jumlah kuisioner yang tidak kembali & 28 & $44,44 \%$ \\
\hline Sumber: Hasil Olah SPSS, 2017 & &
\end{tabular}

Berdasarkan Tabel 1 dapat dilihat bahwa dari 63 eksemplar (100\%) kuesioner yang disebarkan pada 15 Dinas pada Pemerintah Daerah Kabupaten Badung, terkumpul sebanyak 35 eksemplar atau 55,56 persen kuesioner yang kembali dan sebanyak 28 eksemplar atau 44,44 persen kuesioner tersebut tidak kembali dari responden.

Statistik deskriptif penelitian merupakan gambaran kondisi variabel dari kesalahan akuntansi, Sistem Pengendalian Intern Pemerintah (SPIP), dan 
moralitas individu. Berdasarkan hasil kuesioner yang sudah terkumpul ditabulasikan kemudian diolah menggunakan program SPSS. Kondisi variabel yang ditunjukkan oleh tabel deskriptif 2.

Tabel 2.

Statistik Deskriptif

\begin{tabular}{|c|c|c|c|c|c|c|c|c|}
\hline \multirow[t]{2}{*}{ Variabel } & \multirow[t]{2}{*}{$\mathbf{N}$} & \multicolumn{2}{|c|}{$\begin{array}{l}\text { Kisaran } \\
\text { Teoritis }\end{array}$} & \multirow{2}{*}{$\begin{array}{c}\text { Mean } \\
\text { Teoritis }\end{array}$} & \multicolumn{2}{|c|}{ Kisaran Aktual } & \multirow{2}{*}{$\begin{array}{c}\text { Mean } \\
\text { Aktual }\end{array}$} & \multirow{2}{*}{$\begin{array}{c}\text { Standar } \\
\text { Deviasi }\end{array}$} \\
\hline & & Min & Maks & & Min & Maks & & \\
\hline SPIP & 35 & 15,00 & 60,00 & 37,50 & 45,00 & 60,00 & 58,00 & 2,797 \\
\hline MI & 35 & 6,00 & 24,00 & 15,00 & 18,00 & 24,00 & 22,29 & 2,136 \\
\hline KA & 35 & 5,00 & 20,00 & 12,50 & 5,00 & 11,00 & 6,31 & 1,367 \\
\hline
\end{tabular}

Berdasarkan Tabel 2 dapat terlihat bahwa rata-rata jawaban responden terhadap variabel Sistem Pengendalian Intern Pemerintah sebagai independen variabel memiliki nilai mean aktual 58,00 lebih besar dari mean teoritis 37,50 yang menandakan bahwa Pemerintah Daerah Kabupaten Badung telah menerapkan Sistem Pengendalian Intern Pemerintah dengan baik. Apabila jika Sistem Pengendalian Intern Pemerintah diterapkan dengan baik akan mampu mengurangi tingkat kesalahan akuntansi. Semua unsur yang terdapat pada Sistem Pengendalian Intern Pemerintah (SPIP) telah diterapkan dengan baik di Pemerintah Daerah Kabupaten Badung. Standar deviasi pada variabel Sistem Pengendalian Intern Pemerintah sebesar 2.797 dengan ini menandakan bahwa jawaban responden tidak bervariasi.

Variabel moralitas individu juga terlihat bahwa nilai mean aktual sebesar 22,29 lebih besar dari mean teoritis 15,00 . Hal ini menunjukkan bahwa tingkat moralitas individu pegawai Pemerintah Daerah Kabupaten Badung sudah berada pada tahap yang tinggi. Semua unsur yang terdapat pada moralitas individu telah 
I Gusti Agung Gde Dennyningrat dan I D. G. Dharma Suputra. Pengaruh...

dimiliki dengan baik oleh pegawai Pemerintah Daerah Kabupaten Badung. Standar deviasi pada variabel moralitas individu sebesar 2,136 ini menandakan jawaban responden tidak bervariasi.

Variabel kesalahan akuntansi terlihat bahwa rata-rata jawaban responden terhadap variabel kesalahan akuntansi sebagai dependen variabel memiliki nilai mean aktual sebesar 6,31 lebih kecil dari mean teoritis 20,00. Hal ini menunjukkan bahwa tingkat kesalahan akuntansi yang ada di Pemerintah Daerah Kabupaten Badung tergolong rendah. Standar deviasi sebesar 1,367 ini menandakan bahwa jawaban dari responden tidak bervariasi.

Uji validitas digunakan untuk mengukur valid atau sah tidaknya suatu kuesioner. Pengujian validitas menunjukan alat ukur tersebut dapat digunakan untuk mengukur apa yang seharusnya diukur. Syarat minimum suatu kuesioner untuk memenuhi validitas adalah jika koefisien korelasi (r) hitung yang bernilai lebih besar dari $r$ tabel, yaitu di atas 0,3. Nilai $r$ hitung dilihat dari nilai pearson correlation. Berdasarkan Tabel 3 menunjukan bahwa instrumen penelitian dari item-item pernyataan Sistem Pengendalian Intern Pemerintah $\left(\mathrm{X}_{1}\right)$, moralitas individu $\left(\mathrm{X}_{2}\right)$, dan kesalahan akuntansi $(\mathrm{Y})$ adalah valid. Hal ini dikarenakan korelasi antara skor masing-masing pernyataan dengan skor total besarnya diatas 0.30. Suatu kuesioner dikatakan reliabel jika instrumen yang digunakan beberapa kali dengan mengukur objek yang sama akan menghasilkan hasil yang konsisten dari waktu ke waktu. 
ISSN: 2302-8556

E-Jurnal Akuntansi Universitas Udayana Vol.22.2. Februari (2018): 1170-1196

Tabel 3.

Hasil Uji Validitas

\begin{tabular}{|c|c|c|c|c|}
\hline No & Variabel & $\begin{array}{c}\text { Kode } \\
\text { Instrumen }\end{array}$ & $\begin{array}{c}\text { Nilai Pearson } \\
\text { Correlation }\end{array}$ & Keterangan \\
\hline \multirow[t]{15}{*}{1} & Sistem Pengendalian & $\mathrm{X} 1.1$ & 0,591 & Valid \\
\hline & Intern Pemerintah & $\mathrm{X} 1.2$ & 0,562 & Valid \\
\hline & $(\mathrm{X} 1)$ & $\mathrm{X} 1.3$ & 0,476 & Valid \\
\hline & & $\mathrm{X} 1.4$ & 0,677 & Valid \\
\hline & & $\mathrm{X} 1.5$ & 0,470 & Valid \\
\hline & & X1.6 & 0,530 & Valid \\
\hline & & $\mathrm{X} 1.7$ & 0,778 & Valid \\
\hline & & $\mathrm{X} 1.8$ & 0,525 & Valid \\
\hline & & X1.9 & 0,816 & Valid \\
\hline & & $\mathrm{X} 1.10$ & 0,576 & Valid \\
\hline & & $\mathrm{X} 1.11$ & 0,576 & Valid \\
\hline & & $\mathrm{X} 1.12$ & 0,505 & Valid \\
\hline & & $\mathrm{X} 1.13$ & 0,426 & Valid \\
\hline & & $\mathrm{X} 1.14$ & 0,533 & Valid \\
\hline & & $\mathrm{X} 1.15$ & 0,607 & Valid \\
\hline \multirow[t]{6}{*}{2} & Moralitas Individu & $\mathrm{X} 2.1$ & 0,941 & Valid \\
\hline & $(\mathrm{X} 2)$ & $\mathrm{X} 2.2$ & 0,709 & Valid \\
\hline & & $\mathrm{X} 2.3$ & 0,535 & Valid \\
\hline & & $\mathrm{X} 2.4$ & 0,844 & Valid \\
\hline & & $\mathrm{X} 2.5$ & 0,690 & Valid \\
\hline & & $\mathrm{X} 2.6$ & 0,856 & Valid \\
\hline \multirow[t]{5}{*}{3} & Kesalahan Akuntansi & Y.1 & 0,730 & Valid \\
\hline & $(\mathrm{Y})$ & Y.2 & 0,702 & Valid \\
\hline & & Y.3 & 0,713 & Valid \\
\hline & & Y.4 & 0,489 & Valid \\
\hline & & Y.5 & 0,608 & Valid \\
\hline
\end{tabular}

Sumber: Hasil Olah SPSS, 2017

Uji reliabilitas menggunakan teknik cronbach's alpha. Jika hasil dari crobach's alpha menghasilkan nilai alpha diatas 0,60, maka instrumen yang digunakan dikatakan reliabel. Berdasarkan Tabel 4 menunjukan bahwa nilai cronbach's alpha masing-masing variabel memiliki nilai lebih besar dari 0,60. Hal ini menunjukkan bahwa semua pertanyaan dalam kuesioner penelitian ini reliabel dan dapat digunakan. Sebelum melakukan analisis regresi, terlebih dahulu dilakukan uji asumsi klasik dengan tujuan untuk mengetahui apakah model regresi yang digunakan dalam penelitian bebas dari asumsi-asumsi Best, Linear, Unbias, dan Error (BLUE). 
Tabel 4.

Hasil Uji Reliabilitas

\begin{tabular}{lcc}
\hline \multicolumn{1}{c}{ Variabel } & $\begin{array}{c}\text { Cronbach's } \\
\text { Alpha }\end{array}$ & Keterangan \\
\hline Sistem Pengendalian Intern Pemerintah (X1) & 0,838 & Reliabel \\
Moralitas Individu (X2) & 0,855 & Reliabel \\
Kesalahan Akuntansi (Y) & 0,622 & Reliabel \\
Sumber: Hasil Olah SPSS, 2017 & &
\end{tabular}

Uji normalitas bertujuan untuk menguji apakah dalam model regresi variabel terikat dan variabel bebas keduanya mempunyai distribusi normal atau tidak. Model regresi yang baik adalah memiliki distribusi normal atau mendekati normal. Berdasarkan Tabel 5 menunjukan bahwa nilai signifikansi sebesar 0,990 $>0,05$. Hal ini menunjukan bahwa model regresi berdistribusi normal.

Tabel 5.

Hasil Uji Normalitas

\begin{tabular}{lr}
\hline \multicolumn{1}{c}{ Kolmogorov-Smirnov } & Unstandardized Residual \\
\hline $\mathrm{N}$ & 35 \\
Asymp. Sig. (2-tailed) & 0,990 \\
\hline Sumber: Hasil Olah SPSS, 2017
\end{tabular}

Hasil uji heteroskedastisitas pada Tabel 6 menunjukan bahwa nilai sig. dari masing-masing variabel adalah di atas 0,05. Hal ini menunjukan bahwa seluruh variabel tersebut bebas dari heteroskedasitas. Uji heteroskedasitas bertujuan untuk menguji apakah dalam model regresi terjadi ketidaksamaan variance dan residual satu pengamatan ke pengamatan yang lain. Model regresi yang baik adalah yang homoskedasitas atau tidak terjadi heteroskedasitas. Salah satu cara untuk mendeteksi ada atau tidaknya heteroskedasitas digunakan uji glejser. 
Tabel 6.

Hasil Uji Heteroskedasitas

\begin{tabular}{lll}
\hline \multicolumn{1}{c}{ Variabel } & Sig. & Keterangan \\
\hline Sistem Pengendalian Intern & 0,120 & Bebas Heteroskedasitas \\
Pemerintah (X1) & 0,698 & Bebas Heteroskedasitas \\
Moralitas Individu (X2) & &
\end{tabular}

Sumber: Hasil Olah SPSS, 2017

Uji multikolinieritas bertujuan untuk menguji apakah model regresi memiliki korelasi antar variabel bebas. Model regresi yang baik seharusnya tidak terjadi korelasi diantara variabel bebas atau bebas dari gejala multikolinier. Pendeteksian ada tidaknya korelasi antar variabel bebas dapat dilihat dari nilai tolerance atau nilai variance inflation factor (VIF). Jika nilai tolerance lebih dari 10 persen atau VIF kurang dari 10, maka model tidak mengandung gejala multikolinieritas. Hasil uji multikolinieritas selengkapnya dapat dilihat pada Tabel 7.

Tabel 7.

Hasil Uji Multikolinieritas

\begin{tabular}{ccc}
\hline \multirow{2}{*}{ Model } & \multicolumn{2}{c}{ Collinearity Statistics } \\
& Tolerance & VIF \\
\hline X1 & 0,985 & 1,015 \\
X2 & 0,985 & 1,015 \\
\hline
\end{tabular}

Sumber: Hasil Olah SPSS, 2017

Berdasarkan Tabel 7 menunjukan bahwa masing-masing variabel independen memiliki nilai tolerance lebih besar dari 10 persen $(0,1)$ dan nilai VIF kurang dari 10, sehingga model dikatakan tidak mengandung gejala multikolinieritas. Oleh karena model analisis regresi telah memiliki data yang terdistribusi normal dan terbebas dari gejala heteroskedastisitas dan multikolinearitas maka pengujian berikutnya dapat dilanjutkan.

Analisis regresi linear berganda bertujuan untuk mengetahui pengaruh variabel bebas terhadap variabel terikat. Uji hipotesis melalui analisis regresi 
I Gusti Agung Gde Dennyningrat dan I D. G. Dharma Suputra. Pengaruh...

linier berganda (multiple), adalah untuk mencari pengaruh Sistem Pengendalian Intern Pemerintah $\left(\mathrm{X}_{1}\right)$ dan moralitas individu terhadap kesalahan akuntansi (Y). Analisis ini dibantu dengan menggunakan SPSS dan hasilnya dapat dilihat pada Tabel 8.

\section{Tabel 8.}

Hasil Analisis Regresi

\begin{tabular}{|c|c|c|c|c|c|}
\hline \multirow[t]{2}{*}{ Variabel } & \multicolumn{2}{|c|}{$\begin{array}{l}\text { Unstandardized } \\
\text { Coefficient }\end{array}$} & \multirow{2}{*}{$\begin{array}{l}\text { Standardized } \\
\text { Coefficient } \\
\text { Beta }\end{array}$} & \multirow[t]{2}{*}{$\mathbf{t}$} & \multirow[t]{2}{*}{ Sig } \\
\hline & B & Std. Error & & & \\
\hline Constant & 6,371 & 0,458 & & 13,923 & 0,000 \\
\hline X1 & $-0,970$ & 0,099 & $-0,822$ & $-9,842$ & 0,000 \\
\hline $\mathrm{X} 2$ & $-0,389$ & 0,074 & $-0,439$ & $-5,262$ & 0,000 \\
\hline Adjusted $\mathrm{R}_{\text {square }}$ & 0,766 & & & & \\
\hline$F_{\text {hitung }}$ & 56,788 & & & & \\
\hline Sig. $F_{\text {hitung }}$ & 0,000 & & & & \\
\hline
\end{tabular}

Berdasarkan Tabel 8, dapat dibuat persamaan regresi sebagai berikut.

$\mathrm{Y}=6,371-0,970 \mathrm{X}_{1}-0,389 \mathrm{X}_{2}+e$

Berdasarkan persamaan diatas dapat diuraikan nilai konstanta sebesar 6,371 menunjukan bahwa nilai Sistem Pengendalian Intern Pemerintah $\left(\mathrm{X}_{1}\right)$ dan moralitas individu $\left(\mathrm{X}_{2}\right)$ sama dengan nol, maka tingkat kesalahan akuntansi akan meningkat. Nilai koefisien regresi partisipasi anggaran $\left(\beta_{1}\right)$ sebesar $-0,970$ menunjukan bila peran Sistem Pengendalian Intern Pemerintah meningkat satu satuan, akan mengurangi tingkat kesalahan akuntansi dengan asumsi variabel lainnya sama dengan nol. Nilai koefisien regresi partisipasi anggaran $\left(\beta_{2}\right)$ sebesar -0,389 menunjukan bila peran moralitas individu meningkat satu satuan, akan mengurangi tingkat kesalahan akuntansi dengan asumsi variabel lainnya sama dengan nol. 
Pengujian selanjutnya adalah uji kelayakan model atau uji F. Uji statistik F pada dasarnya menunjukkan apakah semua variabel bebas yang dimasukkan dalam model mempunyai pengaruh secara bersama-sama pada variabel dependen. Hasil analisis kelayakan model dapat dilihat pada Tabel 8. Berdasarkan Tabel 8menunjukan bahwa nilai $\mathrm{F}$ hitung sebesar 56,788 dengan nilai signifikan $\mathrm{F}$ atau $p$-value sebesar 0,000 yang lebih kecil dari nilai $\alpha=0,05$. Artinya variabel Sistem Pengendalian Intern Pemerintah serta variabel moralitas individu secara bersamasama (simultan) mempengaruhi kesalahan akuntansi pada Pemerintah Daerah Kabupaten Badung dan model regresi digunakan dianggap layak uji.

Pada penelitian ini, koefesien determinasi yang digunakan adalah nilai dari adjusted $R^{2}$. Koefisien determinasi mengukur seberapa jauh kemampuan model dalam menerangkan variabel-variabel dependen. Pada Tabel 8 menunjukan bahwa besarnya adjusted $R^{2}$ adalah 0,766 . Hal ini menunjukkan bahwa 76,6 persen kesalahan akuntansi dipengaruhi oleh Sistem Pengendalian Intern Pemerintah (SPIP) dan moralitas individu sedangkan sisanya sebesar 23,4 persen dipengaruhi oleh variabel lain yang tidak diteliti.

Berdasarkan hasil uji signifikansi paramater individual pada Tabel 8 menunjukkan bahwa variabel Sistem Pengendalian Intern Pemerintah $\left(\mathrm{X}_{1}\right)$ memiliki $t_{\text {hitung }}$ sebesar $-9,842$ dan tingkat signifikasi sebesar 0,000. Nilai koefisien regresinya menunjukkan arah negatif sebesar -0.970 yang berarti bahwa Sistem Pengendalian Intern Pemerintah (SPIP) terdapat pengaruh negatif pada Kesalahan Akuntansi. Semakin baik pelaksanaan Sistem Pengendalian Intern Pemerintah (SPIP) yang dilakukan di Pemerintah Daerah Kabupaten Badung 
I Gusti Agung Gde Dennyningrat dan I D. G. Dharma Suputra. Pengaruh...

maka akan semakin mengurangi tingkat kesalahan akuntansi. Hasil pengujian ini sejalan dengan hipotesis yang telah dibuat sehingga hipotesis pertama diterima.

Berdasarkan hasil pengujian hipotesis pertama, menunjukan bahwa di lingkungan Pemerintah Daerah Kabupaten Badung Sistem Pengendalian Intern Pemerintah berpengaruh negatif pada kesalahan akuntansi. Semakin baik pelaksanaan Sistem Pengendalian Intern Pemerintah (SPIP) pada Pemerintah Daerah Kabupaten Badung maka tingkat kesalahan akuntansi akan semakin rendah.

Peraturan Pemerintah Nomor 60 Tahun 2008 yang menjelaskan bahwa implementasi Sistem Pengendalian Intern Pemerintah (SPIP) mampu memberikan keyakinan memadai terciptanya suatu Sistem Pengendalian Intern Pemerintah (SPIP) yang dapat mewujudkan tercapainya visi dan misi organisasi melalui kegiatan yang efektif dan efisien, keandalan pelaporan keuangan, pengamanan aset negara, dan ketaatan terhadap peraturan perundang-undangan. Pelaksanaan Sistem Pengendalian Intern Pemerintah (SPIP) harus memperhatikan rasa keadilan dan kepatutan serta mempertimbangkan ukuran, kompleksitas, dan sifat dari tugas dan fungsi instansi pemerintah tersebut.

Unsur-unsur yang terkandung dalam Sistem Pengendalian Intern Pemerintah (SPIP) berfungsi sebagai tolak ukur pengujian Sistem Pengendalian Intern Pemerintah (SPIP) dalam penelitian ini. Kelima unsur Sistem Pengendalian Intern Pemerintah (SPIP) yakni lingkungan pengendalian, penilaian risiko, kegiatan pengendalian, informasi dan komunikasi, serta pemantauan saling 
berkaitan satu sama lain, menyatu pada tindakan dan kegiatan yang dilakukan secara terus menerus oleh pimpinan dan seluruh pegawai.

Berdasarkan jawaban responden Pemerintah Daerah Kabupaten Badung unsur penilaian resiko sudah dilaksanakan dengan baik. Pimpinan melakukan analisis resiko secara lengkap dan menyeluruh tehadap dampak pelaksanaan program dan kegiatan. Sistem Pengendalian Intern Pemerintah (SPIP) di lingkungan Pemerintah Daerah Kabupaten Badung yang kuat dan memadai maka akan tercapai visi dan misi serta tujuan Pemerintah Daerah, keandalan laporan keuangan dengan memperoleh opini Wajar Tanpa Pengecualian (WTP), serta semakin menurunnya dan kecilnya tingkat kesalahan akuntansi di Pemerintah Daerah Kabupaten Badung. Berdasarkan pengalaman kerja dan mengikuti prosedur dalam penyusunan laporan keuangan juga dapat mengurangi tingkat kesalahan akuntansi.

Berdasarkan statistik deskriptif, Sistem Pengendalian Intern Pemerintah (SPIP) pada Pemerintah Daerah Kabupaten Badung sudah dilaksanakan dengan baik. Hal ini dapat dilihat mean aktual Sistem Pengendalian Intern Pemerintah (SPIP) sebesar 58,00 lebih besar dari mean teoritis sebesar 37,50. Kesalahan akuntansi pada Pemerintah Daerah Kabupaten Badung rendah, hal ini dapat dilihat mean aktual kesalahan akuntansi sebesar 6,31 lebih kecil dari mean teoritis sebesar 12,50 .

Hasil penelitian ini sejalan dengan hasil penelitian yang dilakukan Lestari (2014:67) meneliti pengaruh Sistem Pengendalian Intern Pemerintah (SPIP) terhadap kecurangan, sampel penelitian ini adalah pegawai pengelola keuangan 
I Gusti Agung Gde Dennyningrat dan I D. G. Dharma Suputra. Pengaruh...

SKPD Kabupaten Kaur yang meliputi Bendahara, PPK atau PPTK, hasil penelitian ini membuktikan bahwa Sistem Pengendalian Intern Pemerintah yang baik memberikan pengaruh yang signifikan negatif terhadap kecurangan (fraud). Penerapan sistem pengendalian intern pemerintah yang baik Pemerintah Daerah dapat terhindar dari kecurangan. Tanpa pelaksanaan Sistem Pengendalian Intern Pemerintah (SPIP) yang baik, kendala atau resiko yang dapat menyebabkan kerugian besar dapat berlangsung lama. Hasil penelitian ini juga sejalan dengan penelitian Herman (2013) dan Michel (2013) yang menemukan bahwa pelaksanaan sistem pengendalian intern pemerintah dan peran inspektorat terhadap penyalahgunaan aset menunjukkan bahwa pelaksanaan SPIP berpengaruh negatif terhadap penyalahgunaan aset. Hal ini berarti semakin baik pelaksanaan SPIP maka tindakan penyalahgunaan aset akan semakin berkurang.

Hasil uji signifikansi paramater individual pada Tabel 8 menunjukkan bahwa variabel moralitas individu $\left(\mathrm{X}_{2}\right)$ memiliki $\mathrm{t}_{\text {hitung }}$ sebesar $-5,262$ dan tingkat signifikansi sebesar 0,000 . Nilai koefisien regresinya menunjukkan arah negatif sebesar -0.389 yang berarti bahwa moralitas individu terdapat pengaruh negatif pada kesalahan akuntansi. Semakin baik moralitas Individu yang dimiliki pegawai Pemerintah Daerah Kabupaten Badung maka akan semakin mengurangi tingkat kesalahan akuntansi. Hasil pengujian ini sejalan dengan hipotesis yang telah dibuat sehingga hipotesis kedua diterima.

Berdasarkan hasil pengujian hipotesis kedua, menunjukan bahwa moralitas individu pegawai Pemerintah Daerah Kabupaten Badung berpengaruh negatif pada Kesalahan Akuntansi. Semakin baik moralitas individu responden pada 
Pemerintah Daerah Kabupaten Badung maka tingkat kesalahan akuntansi akan semakin rendah.

Berdasarkan jawaban responden Pemerintah Daerah Kabupaten Badung unsur-unsur moralitas individu sudah dilaksanakan dengan baik. Terbentuknya moralitas individu yang baik di lingkungan Pemerintah Daerah Kabupaten Badung maka akan menurunkan tingkat kesalahan akuntansi di Pemerintah Daerah Kabupaten Badung. Berdasarkan pengalaman kerja dan mengikuti prosedur dalam penyusunan laporan keuangan juga dapat mengurangi tingkat kesalahan akuntansi.

Berdasarkan statistik deskriptif, penerapan moralitas individu pada Pemerintah Daerah Kabupaten Badung tehadap pegawainya sudah baik. Hal ini dapat dilihat mean aktual keadilan organisasi sebesar 22.29 lebih besar dari mean teoritis sebesar 15,00. Kesalahan akuntansi pada Pemerintah Daerah Kabupaten Badung rendah, hal ini dapat dilihat mean aktual kesalahan akuntansi sebesar 6,31 lebih kecil dari mean teoritis sebesar 12,50.

Hasil penelitian ini sekaligus memperkuat hasil dari penelitian-penelitian etika yang sebelumnya dilakukan oleh Graham (1994), Liyanarachi (2009), Welton (1994), dan Wilopo (2006), bahwa individu yang memiliki level penalaran moral tinggi akan lebih senstif terhadap isu-isu etika, sehingga akan cenderung melakukan perbuatan yang etis.

Hasil penelitian ini juga mendukung teori tahap perkembangan moral Kohlberg (1971). Pada teori ini disebutkan bahwa dengan semakin tinggi tingkat tahapan moralitas individu, maka individu tersebut akan semakin memperhatikan 
I Gusti Agung Gde Dennyningrat dan I D. G. Dharma Suputra. Pengaruh...

kepentingan orang banyak daripada kepentingan pribadi atau organisasinya sendiri, sehingga berusaha untuk menghindarkan diri dari untuk melakukan kesalahan akuntansi yang dapat merugikan banyak orang.

\section{SIMPULAN}

Berdasarkan hasil analisis dapat disimpulkan bahwa Sistem Pengendalian Intern Pemerintah (SPIP) yang dilakukan pada Pemerintah Daerah Kabupaten Badung terbukti berpengaruh negatif pada kesalahan akuntansi. Semakin baik pelaksanaan Sistem Pengendalian Intern Pemerintah (SPIP) maka tingkat kesalahan akuntansi akan semakin rendah. Moralitas individu yang dimiliki oleh pegawai Pemerintah Daerah Kabupaten Badung berpengaruh negatif pada kesalahan akuntansi. Hal ini menunjukkan semakin tinggi tingkat moralitas individu yang dimiliki pegawai maka akan mengurangi tinkat kesalahan akuntansi yang terjadi pada Pemerintah Daerah Kabupaten Badung.

Saran yang dapat diberikan berdasarkan hasil analisis adalah bagi Instansi agar selalu mengawasi Sistem Pengendalian Intern Pemerintah yang diterapkan agar tetap berjalan dengan baik. Moralitas individu dari para pegawai agar ditingkatkan dengan nilai-nilai karakter agar pegawai dapat bekerja secara jujur dan teliti guna menghindari kesalahan akuntansi yang terjadi pada instansi. Penelitian selanjutnya diharapkan dapat menggunakan variabel-variabel independen seperti ketaatan aturan akuntansi, perilaku tidak etis atau variabel lain yang mempengaruhi seseorang untuk melakukan kesalahan akuntansi. Peneliti selanjutnya agar menambahkan metode lain selain penyebaran kuesioner seperti 
metode interview untuk mendukung penjelasan hasil penelitian dan juga dapat menambahkan variabel yang mempengaruhi kesalahan akuntansi.

\section{REFERENSI}

Afiah, N.N. and Azwari, P.C. 2015. The Effect of the Implementation of Government Internal Control System on the Quality of Financial Reporting of the Local Government and its Impact on the Principles of Good Governance: A Research in District, City, and Provincial Government in South Sumatera. Journal of Accountancy Department. 811818.

Agoes, Sukrisno. 2007. Auditing (Pemeriksaan Akuntan) oleh Kantor Akuntan Publik Jilid 1. Edisi ke 3. Jakarta: LPFE UI.

Aslan, Mecit. 2011. Handbook of Moral and Character Education. International Journal of Instruction. 4(2). 1308-1470.

Boynton, William C., Raymond N. Johnson., 2006. Modern Auditing: Assurance Service and The Integrity of Financial Reporting. $8^{\text {th }}$ Edition. New York : John Willey \& Sons Inc.

Graham, Jill W. 1994. Leadership, Moral Development, and Citizenship Behaviour. Dalam Academy of Management Journal. 37(4): h:765.

Hartadi, Bambang. 2004. Auditing Suatu Pendekatan Komprehensif Per Pos dan Per Siklus. Edisi ke 2. Yogyakarta: PT. Mudaya Kompleks Kampus STIE.

Herman, Lisa A. 2013. Pengaruh Keadilan Organisasi dan Sistem Pengendalian Intern Terhadap Kecurangan. Jurnal. Jurusan Akuntansi pada Fakultas ekonomi Universitas Negeri Padang, Padang.

Hernandez, J. R. dan T. Groot. 2007. Corporate Fraud: Preventive Controls Which Lower Fraud Risk. Journal of Amsterdam Research Centre in Accounting.

Joshua D.K. 2014. Moral Support: How Moral Values Shape Foreign Policy Attitudes. The Journal of Politics. 1-16.

Kohlberg, Lawrence. 1971. Stages of Moral Development as a Basis of Moral Education. Karya Ilmiah. Tidak Diterbitkan.

Lestari, Tia. 2014. Pengaruh Keadilan Organisasi dan Sistem Pengendalian Intern Pemerintah (SPIP) terhadap Kecurangan (Fraud) pada SKPD Kabupaten Kaur. Skripsi Sarjana Jurusan Akuntansi pada Fakultas ekonomi dan bisnis Universitas Bengkulu, Bengkulu. 
Liyanarachi, G. dan C. Newdick. 2009. The Impact of Moral Reasoning and Retaliation on Whistle- Blowing: New-Zealand Evidence. Journal of Business Ethics, 89, pp 37-57.

Mensah, J.K. 2014. Complicity of Auditors in Financial Statement Fraud in Corporate Governance. International Journal of Education and Research. 2(5). 321-334

Michel, Rendika. 2013. Pengaruh Pelaksanaan Sistem Pengendalian Intern Pemerintah dan Peran Inspektorat Terhadap Penyalahgunaan Aset (Studi Empiris pada Pemerintah Daerah Kota Padang). Jurnal. Jurusan Akuntansi pada Fakultas ekonomi, Universitas Negeri Padang, Padang.

Nadya, Dionisia. 2016. Pengaruh Pengendalian Internal dan Moralitas Individu terhadap Kecurangan Akuntansi (Studi Eksperimen pada Pegawai Bagian Keuangan dan Akuntansi Universitas Negeri Yogyakarta). Skripsi. Sarjana Jurusan Akuntansi pada Fakultas ekonomi Universitas Negeri Yogyakarta, Yogyakarta.

Narvaez, Darcia. 2013. The Future of Research in Moral Development and Education. Journal of Moral Education. 46(2). 37-41.

Naval, C. and Jover, G. 2006. The Research on Moral and Civic Education in the Spanish Educational Theory - Evolution and Current Trends. Journal of Social Science Education. 5(2). 93-104.

Patterson, F. 2001. Developments in Work Psychology: Emerging Issues and Future Trends. Journal of Occupational and Organizational Psychology. 74. 381-390.

Peraturan Menteri Dalam Negeri Nomor 64, Tahun 2013 tentang Penerapan Standar Akuntansi Pemerintahan Berbasis Akrual pada Pemerintah Daerah. 2013. Depdagri RI.

Peraturan Pemerintah Nomor 60, Tahun 2008 tentang Sistem Pengendalian Pemerintah. 2008. Depdagri RI.

Permendagri No.13, Tahun 2006 tentang Pengelolaan Keuangan Daerah. 2006. Depdagri RI.

Sanusi, Z.M. 2015. Effects of Internal Controls, Fraud Motives and Experience in Assesing Likelihood of Fraud Risk. Journal of Economics, Business and Management. 3(2). 194-200.

Sugiyono. 2014. Metode Penelitian Bisnis. Bandung: Alfabeta. 
Thilly, Frank. 1918. Moral Values: A Study of The Principles of Conduct. International Journal of Ethics. 29(1). 104-108.

Wadiyo. 2016. Cara Melakukan Koreksi Kesalahan Laporan Keuangan. http://manajemenkeuangan.net/cara-melakukan-koreksi-kesalahanlaporan-keuangan/. Diunduh tanggal 30 Mei 2017.

Wibowo, Hian Ayu Oceani. 2009. Pengaruh Independensi Auditor, Komitmen Organisasi, Gaya Kepemimpinan, dan Pemahaman Good Governance Terhadap Kinerja Auditor (Studi emiris pada Kantor Akuntan publik di Daerah Istimewa Yogyakarta). Skripsi Sarjana Jurusan Akuntansi pada Fakultas ekonomi Universitas Islam Indonesia, Yogyakarta.

Wilopo. 2006. Analisis Faktor-Faktor yang Berpengaruh Terhadap Kecenderungan Kecurangan Akuntansi : Studi pada Perusahaan Publik dan Badan Usaha Milik Negara (BUMN) di Indonesia. Jurnal Riset Akuntansi Indonesia Vol.9.

Zamzami, F. dkk. 2015. The Effectiveness of Fraud Prevention and Detection Methods at Universities in Indonesia. International Journal of Economics and Financial Issues. 6. 66-69 